\title{
Does Saving Really Matter For Growth In Developing Countries? The Case Of A Small Open Economy
}

Olajide S. Oladipo, York College/CUNY, USA

\begin{abstract}
The study employed the Toda and Yamamoto (1995) and Dolado and Lutkepohl (1996) -TYDL methodology to uncover the direction of causal relationship between savings and economic growth in Nigeria between 1970 and 2006. The empirical results suggest that savings and economic growth are positively cointegrated, indicating a stable long-run equilibrium relationship. Further, the findings revealed a unidirectional causality between savings and economic growth and the complementary role of FDI in growth.
\end{abstract}

Keywords: Cointegration, FDI, Savings and Economic Growth

\section{INTRODUCTION}

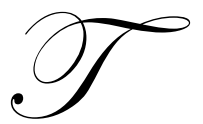

he relationship between savings and economic growth has received increased attention in recent years, especially in developed and emerging economies [see Bacha (1990), DeGregorio (1992), Levine and Renelt (1992), and Jappelli and Pagano (1994)]. This might not be unconnected to the central underpinning of Lewis's (1955) traditional development theory that increasing savings would accelerate economic growth. Research efforts by Kaldor (1956) and Samuelson and Modigliani (1966) examined how different savings behaviours would induce economic growth.

A survey of the role of savings in economic development by the World Bank (1993) revealed that 'countries with higher savings rates have grown at faster rates than those with low saving rates'. Thus, the Bank opined that policies which promote saving are germane in developing countries as higher savings will contribute to higher economic growth. However, recent empirical findings have been mixed and, as a result, the debate on savings and growth remain, at best, inconclusive. Studies by Gavin, et al (1997), Sinha and Sanha (1998), Saltz (1999), and Agrawal (2001), revealed that economic growth rates preceded savings growth rates while Cullison (1993), Alguacil, Cuadros and Orts (2004), and recently Lorie (2007), found the reverse causality.

Of course, the vast empirical literature, though contributing immensely to explaining the savings-growth nexus, suffers from a number of shortcomings. These include reliance on cross section data, ${ }^{1}$ which may not satisfactorily address country specific issues, inappropriate econometric techniques and concentration mainly on the use of the bivariate causality test, and the likely omission-of-variable bias. In fact, many studies omitted the complementary role of foreign resources inflow, especially in emerging and developing economies.

The point of departure here is to exploit time series features, the information contained in the long-run relationship between the variables and employ Toda and Yamamoto's (1995) methodology, thus avoiding pitfalls in previous studies. Our paper investigates the causal relationship between the growth rate of savings and economic growth in bivariate and multivariate systems for Nigeria. Given the growing importance of foreign resources inflow

\footnotetext{
${ }^{1}$ Studies by Demetriades and Hussien (1996) and Arestis and Demetriades (1997) revealed that there are significant dangers from lumping together in cross section equations countries with very different experiences which may reflect different institutional characteristics, different policies and differences in their implementation.
} 
in many developing countries, particularly the Nigerian economy, the paper intends to uncover the likely complementary role of foreign resources inflow in this relationship. This study is germane because discovering the appropriate direction of causation has important policy implications for development strategies in developing countries, and particularly in Nigeria.

\section{LITERATURE REVIEW}

Quite a number of recent studies examine the dynamic relationship of savings and economic growth. Caroll and Weil (1994) used five year averages of the economic growth rate and savings for OECD countries and found that economic growth Granger caused savings. However, the reverse was obtained when dummies were included in their estimation. Using Granger causality tests, findings by Sinha and Sinha (1998) and Sinha (1999) found that economic growth rate Granger caused the savings growth rate for Mexico and Sri Lanka respectively. Employing time series data between 1960 and 1997, Bhaharumshah et al (2003) found that savings does not Granger cause economic growth rate for Singapore, South Korea, Malaysia, Philippines and Thailand. Also, addressing the relationship between domestic savings and economic growth for various economies with different income levels, Mohan (2006) concluded using cross section data from 1960 to 2001 and Granger causality methodology, that economic growth rate Granger caused savings growth rate in eight high income countries (HIC) - Sweden, Iceland, Finland, UK, Korea, Japan, Canada, and Norway- except in Singapore, 3 lower-middle income countries -Algeria, Thailand, and Colombia- except Egypt and Ecuador, 2 low income countries - Nigeria and Senegal - except Indonesia,. There was bi-directional causation in all upper-middle income countries -Chile, Argentina, Brazil, and South Africa- except Malaysia.

Employing Toda and Yamamoto (2005) methodology to test for causality using data from India and Sri Lanka, Mavrotas and Kelly (2001) found no causality between GDP growth and private savings for India and a bidirectional relationship for Sri Lanka. Also using the procedure developed by Toda and Yamamoto (1995) and Dolado and Lutkepohl (1996) and the inclusion of foreign resources inflow in multitivariate systems, contrary to the reverse causation by Sinha and Sinha (1998), Alguacil, Caudros and Orts (2004), found evidence in favour of Solow's model prediction that higher savings leads to higher economic growth for Mexico. The observed conflicting results for Sri Lanka and Mexico might not be unconnected to data, methodology, and the important role of omitted variable(s).

However, a cursory observation of the literature revealed that research has been focused on developed and emerging economies. Despite the importance and the likely policy guidance for development strategies for African economies, empirical research on African countries has been very scanty. Further, with the exception of Adebiyi (2005), available studies used cross section data. Using cross section data between 1960 and 1997 and Granger causality methodology, Anoruo and Ahmadi (2001) examined the causal relationships between the growth rate of domestic savings and economic growth for seven African countries - namely Congo, Cote d'Ivoire, Ghana, Kenya, Nigeria, South Africa and Zambia. Their studies found that savings are co-integrated in all of the countries except for Nigeria and that economic growth Granger-causes the growth rate of domestic savings for all the countries considered except Congo where reverse causality was obtained. Further, for Cote d'Ivoire and South Africa, bidirectional causality was found. Adebiyi (2005) employed quarterly data spanning between 1970 and 1998 to investigate savings and growth relationships in Nigeria using Granger causality tests and impulse response analysis. Adebiyi concluded that growth, using per capital income, is sensitive to, and has an inverse effect on savings. All these studies above omitted the role of foreign resource inflows and as a result do not consider either the role played by foreign resource inflows in complementing domestic saving or the likely beneficial effects of foreign inflows on domestic savings. Thus, to examine the complementarity role of foreign resource inflows, redress imbalance in the literature, and allow for country specific policy, we investigate the relationship between economic growth rate and the growth rate of savings for Nigeria.

\section{DATA AND METHODOLOGICAL ISSUES}

The study employs annual data from 1970 to 2006 to examine the causal relationship between economic growth and the growth rate of savings. Data for the research are obtained from Central Bank of Nigeria (CBN), Federal Office of Statistics (FOS), International Monetary Fund (IMF) and the World Bank (WB). The gross 
domestic product (GDP) is used in place of domestic income and domestic saving and foreign direct inflow are both deflated using the GDP deflator.

The first step involves carrying out unit root tests on all the variables of interest using both Augmented Dickey-Fuller (ADF) and Phillips-Perron tests at 1\% and 5\% levels of significance. This is to ensure that the series enter the model in a non-explosive form. Further, to determine whether there exists a long-run relationship among domestic saving $(T S A V)$, foreign resource inflow $(F D I)$ and economic growth $(G D P)$, we use the multivariate cointegration approach by Johansen (1992), and Johansen and Juselius (1990) to test for cointegration. The maximum eigenvalue $\left(\lambda_{\max }\right)$ and trace $\left(\lambda_{\text {trace }}\right)$ tests statistics are used to estimate the co-integration rank $r$ (the number of independent co-integrating vector):

$$
\begin{aligned}
& \lambda_{\text {trace }}(r)=-T \sum_{i=r+1}^{n} \ln \left(1-\lambda_{i}\right) \\
& \lambda_{\max }(r, r+1)=-T \ln \left(1-\lambda_{r+1}\right)
\end{aligned}
$$

where $\lambda_{i}$ is the estimated values of characteristic root or the eigenvalue and $\mathrm{T}$ is the number of usable observation. The general form of the vector correction model is given by:

$$
\Delta y_{t}=a_{0 y}+a_{1 y} t-\Pi_{y} z_{t-1}+\sum_{i=1}^{p-1} \Gamma_{i y} \Delta z_{t-1}+\Psi_{y} w_{t}+\varepsilon_{t}, \quad t=1,2, \ldots \ldots \ldots \ldots \ldots \ldots . . n
$$

where $z_{t}=\left(y_{t}^{\prime}, x_{t}^{\prime}\right)^{\prime}, y_{t}$ is an $m \times 1$ vector of endogenous variables $I(1)$ and $w_{t}$ is a $q \times 1$ vector of exogenous or deterministic $I(0)$ variables.

Of course, many tests of Granger-type causality have been derived and implemented to test the direction of causality -Granger (1969), Sims (1972) and Gwekes et al (1983). These tests are based on null hypotheses formulated as zero restrictions on the coefficients of the lags of a subset of the variables. Thus, the tests are grounded in asymptotic theory ${ }^{2}$. Other shortcomings of these tests have been discussed in Toda and Phillips (1994). Also, it is well documented that the exclusion of relevant variables induces spurious significance and inefficient estimates (Maddala, 2001; Gujarati, 2006).

In dealing with these problems, we employ Toda and Yamamoto (1995) and Dolado and Lutkepohl (1996) -TYDL- methodology. They propose a technique that is applicable irrespective of the integration and conintegration properties of the system. The method involves using a Modified Wald statistic for testing the significance of the parameters of a VAR(s) model (where $s$ is the lag length in the system) ${ }^{3}$. Thus, the estimation of a $\operatorname{VAR}\left(s+d_{\text {max }}\right)$ guarantees the asymptotic $\chi^{2}$ distribution of the Wald statistic, where $d_{\max }$ is the maximal order of integration in the model ${ }^{4}$. The lag length of the variables in the causal models are set according to Akaike Information Criterion (AIC). Since lagged dependent variables appear in each equation of the aforementioned causal models, their presence is expected to purge serial correlation among the error terms.

\footnotetext{
${ }^{2}$ Of course, a common problem with Granger causality tests is the likely existence of stochastic trends in the variables.

${ }^{3}$ As demonstrated by Toda and Yamamoto (1995), if variables are integrated of order $\mathrm{d}$, the usual selection procedure is valid whenever $k \geq d$. Thus, if $d=1$, the lag selection is always consistent.

${ }^{4}$ The traditional $\mathrm{F}$ tests and its Wald test counterpart to determine whether some parameter of a stable VAR model are jointly zero are not valid for non-stationary processes, as the test statistics do not have a standard distribution (Toda and Phillips, 1993).
} 
The lag length, using the Akaike Information Criterion (AIC), is determined to be 2. To increase the number of lags in the WALD model up to the maximum cointegration level of variables entered in the model is crucially fundamental in opting for the Toda and Yamamoto causality testing procedure. The Toda and Yamamoto approach is an alternative causality testing approach based on the Granger non-causality equation but augmented with extra lags determined by the potential order of integration of the series causally tested.

\section{EMPIRICAL FINDINGS}

A graphical representation of the series in logarithmic form is displayed in Figure 1. Figure 1 represents the cross plots of domestic saving and foreign investment flows in relation to domestic income. The most striking feature to emerge is that both savings and foreign direct investment appear positively related to domestic output and also the saving-income relation. This correlation, however, does not imply causality and thus leaves unsettled the debate concerning the direction of the saving-growth nexus for Nigeria.

Figure 1: Domestic Savings and Foreign Resources Inflows in Relation to Domestic Income
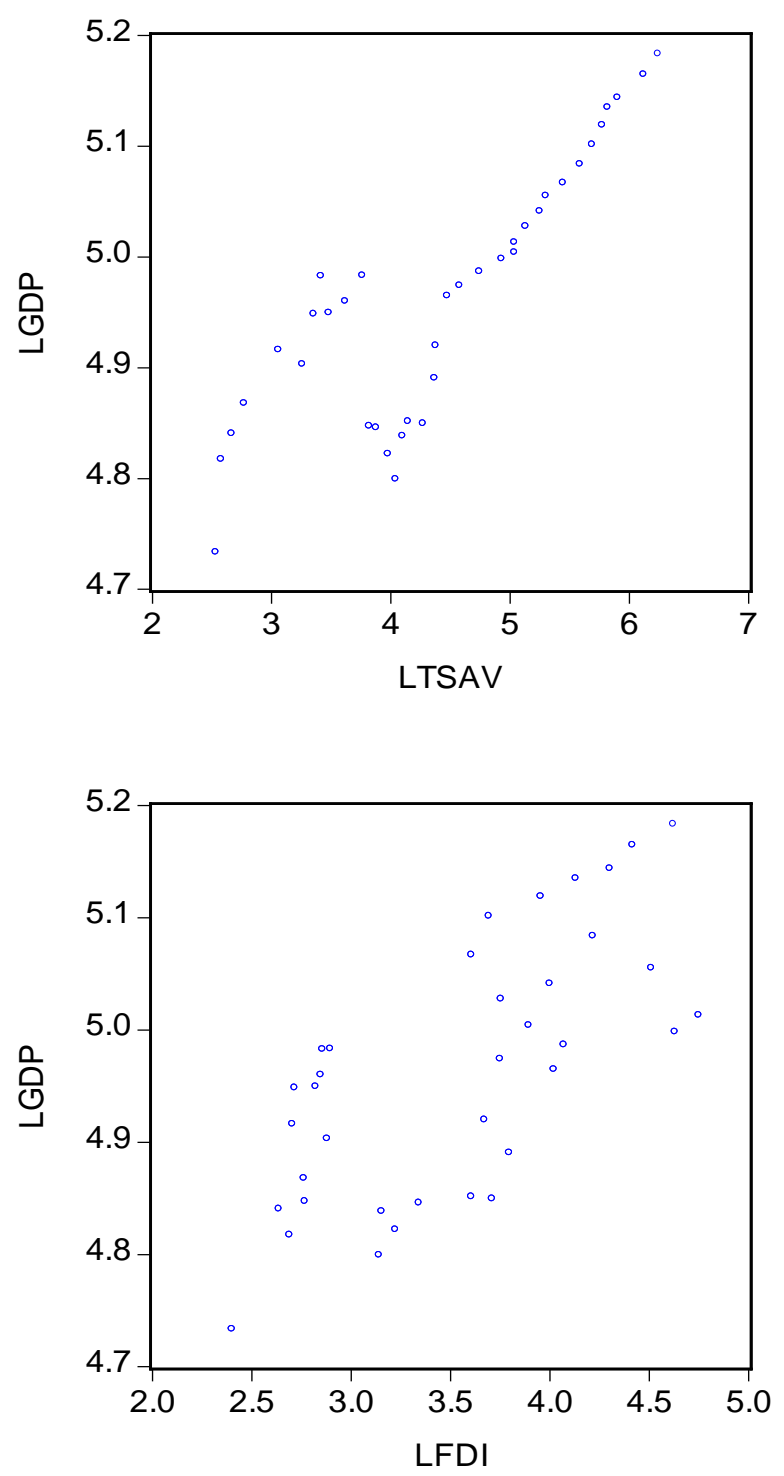
We employed the Augmented Dickey-Fuller (ADF) and Phillips-Peron (PP) tests to examine the integrating order of the variables under consideration. The results of the unit root tests for the variables in their levels and first differences are reported in Table 1. LTSAV, LFDI, and LGDP stand for the logarithms of total domestic savings, foreign direct investment and the gross domestic products respectively. Our results revealed that all the variables are $I(1)$.

Table 1: Test of unit root hypothesis. $H_{0}$ : One unit root; $H_{1}$ : No unit root

\begin{tabular}{|c|c|c|c|c|c|c|}
\hline \multirow[t]{2}{*}{ Variable } & \multicolumn{3}{|c|}{ ADF statistics } & \multicolumn{3}{|c|}{ PP statistics } \\
\hline & $\tau(i)$ & $\tau(i i)$ & $\tau(i i i)$ & $Z\left(t_{\alpha}\right)(i)$ & $Z\left(t_{\alpha^{*}}\right)(i i)$ & $Z\left(t_{\alpha^{*}}\right)(i i i)$ \\
\hline LTSAV & 1.79 & -0.84 & -2.93 & 0.84 & -0.19 & -2.01 \\
\hline$\triangle L T S A V$ & -8.75 & -5.09 & -5.08 & -8.87 & -4.26 & -4.19 \\
\hline$L F D I$ & 2.30 & -0.56 & -2.29 & 1.96 & -1.49 & -2.33 \\
\hline$\triangle L F D I$ & -12.56 & -7.57 & -7.45 & -12.77 & -15.24 & -14.99 \\
\hline$L G D P$ & 2.21 & -0.99 & -1.13 & 1.82 & -1.22 & -2.12 \\
\hline$\triangle L G D P$ & -5.54 & -5.95 & -5.27 & -5.77 & -5.94 & -5.86 \\
\hline \multicolumn{7}{|c|}{$\begin{array}{l}\text { Critical Values for observations } \\
\text { Significant levels }\end{array}$} \\
\hline $1 \%$ & -2.63 & -3.63 & -4.34 & -2.63 & -3.63 & -4.24 \\
\hline $5 \%$ & -1.95 & -2.95 & -3.58 & -1.95 & -2.95 & -3.58 \\
\hline
\end{tabular}

Notes: (i), (ii) and (iii) indicate the model statistics without either drift or trend, with drift and with drift and trend. The optimal lag length used for the augmented Dickey-Fuller tests (ADF) and the truncation lag parameter in the Phillips and Perron tests (PP) were determined using Akaike Information Criterion (AIC).

Given that our series are $I(1)$, we examined the long-run relationships among the variables. The results of the Johansen multivariate cointegration test are shown in Table 2 below.

Table 2: Multivariate Cointegration Tests Results

\begin{tabular}{lccc}
\hline \multicolumn{1}{l}{ Null } & \multicolumn{1}{c}{ Alternative } & \multicolumn{1}{c}{ Trace Statistic } & 5\% Critical Value \\
\hline Panel (A) Unrestricted Cointegration Rank Test (Trace Test) & \\
$r=0$ & $r=1$ & 74.04 & 67.86 \\
$r \leq 1$ & $r=2$ & 36.30 & 43.79 \\
& & \\
Panel (B) Unrestricted Cointegration Rank Test (Maximal Eigenvalue Test) & \\
$r=0$ & $r=1$ & 37.73 & 27.58 \\
$r \leq 1$ & $r=2$ & 20.23 & 22.13 \\
\hline
\end{tabular}

Note: $r$ indicates the number of cointegrating vectors

According to both maximal eigenvalue and trace statistic tests, our results indicate the existence of one cointegrating vector. Thus, the Johansen cointegration test suggests that there is a long-run relationship between domestic savings and economic growth. Hence, the long-run relationship between economic growth and savings is found to be positive in each cointegrating vector. This suggests causality in at least one direction. 
Table 3: Tado-Yamamoto Causality (Modified WALD) Test Results

\begin{tabular}{lcc}
\hline$H_{0}$ & $\chi^{2}$ & P-value \\
\hline $\mathrm{S} \rightarrow \mathrm{GDP}$ & 4.62371 & 0.00007 \\
$\mathrm{FDI} \rightarrow \mathrm{GDP}$ & 6.48452 & 0.00812 \\
$\mathrm{~S}, \mathrm{FDI} \rightarrow \mathrm{GDP}$ & 16.5873 & 0.00004 \\
$\mathrm{GDP} \rightarrow \mathrm{S}$ & 2.95534 & 0.67899 \\
$\mathrm{~S} \rightarrow \mathrm{FDI}$ & 0.88652 & 0.40367 \\
$\mathrm{FDI} \rightarrow \mathrm{S}$ & 5.84722 & 0.03239 \\
$\mathrm{GDP}, \mathrm{FDI} \rightarrow \mathrm{S}$ & 0.78761 & 0.34762 \\
\hline
\end{tabular}

Table 3 reports the $\chi^{2}$-test statistic obtained, together with the estimate $p$-values and the results for the multivariate and bivariate causality tests. Our results confirm not only the Solow's model prediction that savings precedes and causes economic growth, but also the existence of an FDI-growth nexus, as there exists a positive causal relationship going from saving and FDI to growth, which confirms the expected beneficial effects of FDI to domestic income in Nigeria.

\section{CONCLUSION AND POLICY IMPLICATIONS}

The paper presented some rather careful tests of causality between domestic savings and economic growth, in both bivariate and multivariate systems, using the Toda and Yamamoto methodology. The empirical results suggest that savings and economic growth are positively cointegrated, indicating a stable long-run equilibrium relationship. Further, the findings revealed a unidirectional causality between savings and economic growth and the complementary role of FDI in growth. The Nigerian government needs to formulate policies that would enhance saving to promote economic growth. Also, policies that would improve the confidence of the foreign investors might lead to sustainable economic growth in Nigeria.

\section{REFERENCES}

1. Adebiyi (2005) Saving-Growth relationship in Nigeria: An Empirical Evidence. African Review of Money Finance and Banking, 159-178.

2. Agrawal, P. (2001) The relation between Savings and Growth: Cointegration and Causality Evidence from Asia, Applied Economics, 33, 499-513.

3. Alguacil, M., Cuadros, A. and V. Orts (2004) Does Saving really matter for Growth? Mexico (1970-2000). Journal of International Development, March, 16, 2: 281-290.

4. Anoruo, E and Ahmad, Y (2001) Causal Relationship between Domestic Savings and Economic Growth: Evidence from Seven African Countries, African Development Bank, Blackwell publisher, Oxford.

5. Attanasio, O., L. Picci, and A. Scorcu (2000): "Saving, Growth, and Investment: A Macroeconomic Analysis Using a Panel of Countries," Review of Economics and Statistics, 82(1).

6. Bacha, E.L (1990) A Three-Gap Model of Foreign Transfers and the GDP Growth Rate in Developing Countries, Journal of Development Economics, Vol. 32, 279-96.

7. Baharumshahl et al (2003) Savings Dynamic in Asian Countries, Journal of Asian Economics, Vol. 13: 827-845.

8. Carroll, C. D., and D. N. Weil (1994): "Saving and Growth: A Reinterpretation," Carnegie-Rochester Conference Series on Public Policy, 40, 133-192

9. ---------, Overland, J and D. N Weil (2000) Saving and Growth: with Habit Formation, American Economic Review, Vol. 90, 3: 351-55.

10. Central Bank of Nigeria (CBN) Statistical Bulletin (Various Issues), www.cenbank.org

11. Cullison, W. E. (1993) Savings Measure as Economic Growth Indicators. Contemporary Policy Issues, Vol. 11, January.

12. DeGregorio, J (1992) Economic Growth in Latin America, Journal of Development Economics, Vol. 39: $59-84$. 
13. Demetriades, $\mathrm{P}$ and Hussien, K (1996) Does Financial Development Cause Economic Growth: Time Series Evidence from 16 Countries. Journal of Development Economics, Vol. 51, No. 2, 387-411.

14. Dolado, J. and Lutkepohl, H (1996) Making Wald Tests work for Cointegrated VAR Systems. Econometric Review, 15, 369-386.

15. Edwards, S. 1995. "Why are Savings Rates so Different Across Countries?: An International Comparative Analysis", NBER Working Paper No. 5097

16. Enders, W (1995) Applied Econometric Time Series, John Wiley \& Sons, Inc.

17. Gavin, M., Hausmann, R. and E. Talvi (1997) Saving behaviour in Latin America: Overview and Policy issues, In: Hausmann, R., Reisen, H. (eds), Promoting Savings in Latin America. Organization for Economic Cooperation and Development and Inter-America Development Bank, Paris.

18. Geweke, J., Meese, R. and Dent, W. T. (1983) Comparing alternative tests of causality in temporal systems:Analytic results and experimental evidence, Journal of Econometrics, 21, 161 - 94.

19. Granger, C. W. J. (1969) Investigating causal relations by econometric models and cross spectral methods, Econometrica, 37, 424- 38

20. Gujarati, D.N (2006) Essential of Econometrics, $3^{\text {rd }}$ Edition, McGraw Hill

21. International Monetary Fund (2007) International Financial Statistics, Online version, December.

22. Jappelli, T and M. Pagano (1994) Savings, Growth and Liquidity Constraints, Quarterly Journal of Economics, 109: 83-109

23. Johansen, S. (1988) Statistical Analysis of Cointegrating Vectors. Journal of Economic Dynamics and Control, 12, 231-254.

24. Johansen, S; 1991, "Estimation and Hypothesis Testing of Cointegration Vectors in Gaussian Vector Autoregressive Models"; Econometrica, 59(6), 1551-80

25. Johansen, S. (1992) Testing Weak Exogeneity and Order of Cointegration in UK Money Demand Data. Journal of Policy Modeling, 14, 313-334.

26. Johansen, S and K. Juselius (1990) Maximum Likelihood Estimation and Inference on Cointegration with Applications to Demand for Money. Oxford Bulletin of Economics and Statisticis, Vol. 52, May, 169-210.

27. Kaldor, N (1956) Alternative Theories of Distribution, Review of Economic Studies, 23(2): 83-100.

28. Levine, Ross E., and David Renelt (1992): "A Sensitivity Analysis of Cross-Country Growth Regressions," American Economic Review, 82, 942-963

29. Lewis, W. A (1955) The Theory of Economic Growth. Homewood, III: Irvin.

30. Lorie, H. (2007) Mobilizing Savings for Sustainable High Growth: Lesson from Asia for Pakistan. A presentation at PIDE, Islamabad, August.

31. Maddala, G.S (2001) Introduction to Econometrics, $3^{\text {rd }}$ Edition, Wiley and Sons, Inc

32. Mavrotas, G. and Kelly, R (2001) Old Wine in New Bottles> testing Causality between Savings and Growth, The Manchester School, Vol. 69: 97-105.

33. McKinnon, R.J. 1973. "Money and Capital in Economic Development” Brookings, Washington DC

34. Modigliani, F. (1970): "The Life Cycle Hypothesis of Saving and Inter-Country Differences in the Saving Ratio," in Induction, Growth, and Trade: Essays in Honor of Sir Roy Harrod, ed. by W. A. Eltis. Clarendon Press, London

35. Modigliani, F. 1992. "Savings in Developing Countries: Income, Growth and Other Factors" Pacific Basin Capital Markets Research, Vol. 3, pp.23-35

36. Mohan, R. (2006) Causal Relationship between Savings and Economic Growth in Countries with different Income Levels. Economic Bulletin, Vol. 5, No. 3: 1-12.

37. Paxson, C. H .(1995): "Saving and Growth: Evidence from Micro Data," European Economic Review, 40, 255-88

38. Phillips. P.C.B and P. Perron (1988) Testing for a Unit Root in Time Series Regression, Biometrika, 75 (2) 336-346.

39. Saltz, I.S (1999) An Examination of the Causal Relationship between Savings and Growth in the Third World, Journal of Economics and Finance, Vol. 23: No.1 90-98.

40. Samuelson, P and P. Modigliani (1966) The Passinetti Paradox in Neo-Classical and More General Models, Review of Economic Studies, Vol. 33, 269-301.

41. Shaw, E.S; 1973, "Financial Deepening in Economic Development"; Oxford University Press

42. Sinha, D and Sinha T (1998) Cart Before Horse? The Saving-Growth Nexus in Mexico, Economics Letter, 61:43-47. 
43. -------- (1999) Saving and Economic Growth in Sri Lanka. Indian Journal of Applied Economics, Vol. 8, No.3, 163-174

44. $\quad$-------- (2000) Tests of Granger Causality Between Saving and Economic Growth in the Philippines, Journal of Social and Economic Development, Vol. II, No. 2.

45. Sims, C. A. (1972) Money, income and causality, American Economic Review, 62, $540 \pm 52$.

46. Solow, R.M; 1956, “A Contribution to the Theory of Economic Growth"; Quarterly Journal of Economics, 70(1), 65-94

47. Toda, H.Y. and P.C.B. Phillips (1994) : "Vector Autoregressions and Causality: A Theoretical Overview and Simulation Study", Econometric Reviews 13, 259-285

48. Toda, H.Y. and Yamamoto (1995) Statistical inference in Vector Autoregressions with possibly integrated processes. Journal of Econometrics, 66, 225-250.

49. World Bank (1993) The East Asian Miracle: Economic Growth and Public Policy, New York: Oxford University Press

50. World Bank. World Development Indicators, Various Issues. World Bank: Washington DC. 